九州大学学術情報リポジトリ

Kyushu University Institutional Repository

\title{
Essentiality of Mineral Mixture Supplement to White Fish Meal Diet for Tiger Puffer
}

Furuichi, Masayuki

Fishery Research Laboratory, Kyushu University

Furusho, Yasuyuki

Fishery Research Laboratory, Kyushu University

Matsui, Sei ichi

Fishery Research Laboratory, Kyushu University

Kitajima, Chikara

Fishery Research Laboratory, Kyushu University

https://doi.org/10.5109/24194

出版情報: 九州大学大学院農学研究院紀要. 42 (1/2)，pp.77-85，1997-12. Kyushu University バージョン：

権利関係 : 
J. Fac. Agr., Kyushu Univ., 42 (1·2), 77-85 (1997)

\title{
Essentiality of Mineral Mixture Supplement to White Fish Meal Diet for Tiger Puffer*
}

\author{
Masayuki Furuichi, Yasuyuki Furusho, Seiichi Matsui \\ and Chikara Kitajima
}

\author{
Fishery Research Laboratory, Kyushu University, Tsuyazaki, \\ Fukuoka 811-33, Japan.
}

(Received July 30, 1997 and accepted August 25, 1997)

\begin{abstract}
The essentiality of mineral mixture supplement to a white fish meal diet for tiger puffer Takifugu rubripes was investigated. Fish were fed on the white fish meal diet with or without a mineral mixture supplement for 10 weeks. Growth was significantly inferior in the mineral non-supplemented group to the supplemented group. Lower hepatosomatic index and higher hemoglobin and hematocrit values were found in the non-supplemented group. Plasma $\mathbf{P}$ and $\mathrm{Mg}$ contents and bone ash, $\mathrm{P}$, and Ca contents were lower in the mineral non-supplemented group. Bone deformities were observed in most of the fish of non-supplemented group. So, the mineral mixture supplement was found to be essential in a white fish meal diet for tiger puffer.
\end{abstract}

\section{INTRODUCTION}

White fish meal, which is a major protein source in commercial diets, contains a large amount of minerals. However, the bioavailability of various minerals in fish meal to fish was found to be low due to interactions among minerals (Watanabe et al., 1988). Studies so far done about the availability of minerals in fish meal are with fresh water species. The bioavailability was low for most of the minerals, as $\mathrm{P}, \mathrm{Mg}, \mathrm{Mn}, \mathrm{Zn}, \mathrm{Cu}$, and Co in carp (Takamatsu et al., 1975; Ogino et al., 1979; Shitanda et al., 1979; Satoh et al., 1983a, 1987 a,b), P, Mg, Mn, Zn, and $\mathrm{Cu}$ in rainbow trout (Ketola, 1975; Ogino et al., 1979; Takeuchi et al., 1981; Satoh et al., 1983b,c, 1987c,d) and Zn in channel catfish (Gatlin and Wilson, $1983,1984)$. Very little information is available on the mineral requirement of marine fish. Because, as fish can easily absorb minerals from surrounding water (Lovelace and Podoliak, 1952; Ichikawa and Oguri, 1961; Templeton and Brown, 1963; Lall, 1979; Love, 1980), a dietary supplement of minerals has been thought to be dispensable in case of marine fish. Recently, P and Fe supplements to a purified casein based diet was found to be essential for red sea bream (Sakamoto and Yone, 1976a; Sakamoto, 1981) and Ca, P and Fe supplements for yellowtail. ${ }^{*}$ In the present study, the availability of minerals in a white fish meal diet was investigated for tiger puffer Takifugu rubripes.

\section{MATERIALS AND METHODS}

\section{Experimental diets}

Two experimental diets were prepared with or without a mineral mixture supplement

\footnotetext{
* Contribution from Fishery Research Laboratory, Kyushu University, No. 225.

${ }^{*}$ Makino, H. et al.: Abst. Metg. Japan. Soc. Fisheries Sci., April, 1989, p. 43 (in Japanese).
} 
(Tables 1 and 2). White fish meal was used as a dietary protein source. All the ingredients were mixed thoroughly, and an aliquot of water was added. Then, pellets of appropriate size were made using a laboratory type pelleter. The diets were then half dried and preserved under $-20^{\circ} \mathrm{C}$. The proximate and mineral compositions of experimental diets are shown in Table 3.

Table 1. Composition of the experimental diets for tiger puffer (\%)

\begin{tabular}{lcc}
\hline & \multicolumn{2}{c}{ Mineral mixture supplement } \\
\cline { 2 - 3 } & With & Without \\
\hline White fish meal & 60 & 60 \\
$\alpha$-Potato starch & 10 & 10 \\
Dextrin & 10 & 10 \\
Pollack liver oil & 5 & 5 \\
Vitamin mixture $^{*+}$ & 3 & 3 \\
Mineral mixture $^{*-2}$ & 8 & 0 \\
Carboxymethylcellulose $^{\alpha-C e l l u l o s e}$ & 4 & 4 \\
\hline
\end{tabular}

+ Halver's vitamin mixture (1957) $+\alpha$-Cellulose.

$\because$ See Table 2.

Table 2. Mineral mixture supplemented to the experimental diet.

\begin{tabular}{lr|lr}
\hline Major elements & \multicolumn{1}{c|}{$(\mathrm{g})$} & Trace elements & (mg) \\
\hline $\mathrm{KCl}$ & 6.54 & $\mathrm{AlCl}_{3} \cdot 6 \mathrm{H}_{2} \mathrm{O}$ & 9.0 \\
$\mathrm{MgSO}_{4} \cdot 7 \mathrm{H}_{2} \mathrm{O}$ & 6.81 & $\mathrm{ZnSO}_{4} \cdot 7 \mathrm{H}_{2} \mathrm{O}$ & 176.0 \\
$\mathrm{NaH}_{2} \mathrm{PO}_{4} \cdot 2 \mathrm{H}_{2} \mathrm{O}$ & 42.81 & $\mathrm{MnSO}_{4} \cdot 4-6 \mathrm{H}_{2} \mathrm{O}$ & 39.5 \\
$\mathrm{Fe}-$ citrate & 1.48 & $\mathrm{CuCl}$ & 5.5 \\
Ca-lactate & 24.51 & $\mathrm{KI}$ & 8.5 \\
$\alpha$-Cellulose & 17.56 & $\mathrm{CoCl}_{3} \cdot 6 \mathrm{H}_{2} \mathrm{O}$ & 51.5 \\
\hline Total $(\mathrm{g})$ & & 100 &
\end{tabular}

Table 3. Proximate and mineral compositions of the experimental diets for tiger puffer

\begin{tabular}{|c|c|c|}
\hline & \multicolumn{2}{|c|}{ Mineral mixture supplement } \\
\hline & With & Without \\
\hline \multicolumn{3}{|l|}{ (Proximate composition) } \\
\hline Moisture (\%) & 25.4 & 23.6 \\
\hline Crude protein (\% d. m.) & 47.3 & 47.6 \\
\hline Crude lipid $\quad(\%$ d. m.) & 9.8 & 9.0 \\
\hline Crude ash & 18.5 & 13.5 \\
\hline \multicolumn{3}{|l|}{ (Mineral composition) } \\
\hline $\mathrm{P} \quad(\%)$ & 2.23 & 1.47 \\
\hline $\mathrm{Ca}$ & 3.68 & 2.54 \\
\hline $\mathrm{Mg} \quad(\mathrm{mg} / 100 \mathrm{~g})$ & 186 & 132 \\
\hline $\mathrm{K} \quad(\mathrm{mg} / 100 \mathrm{~g})$ & 568 & 294 \\
\hline $\mathrm{Fe} \quad(\mathrm{mg} / 100 \mathrm{~g})$ & 28.3 & 7.3 \\
\hline
\end{tabular}




\section{Fish and feeding trials}

Tiger puffer Takifugu rubripes juvenile obtained from the Fukuoka Prefectural Sea Farming Center were used for the experiment. Fish were acclimated to indoor culture tank conditions for 2 weeks prior to the initiation of rearing experiment. At the beginning of the experiment, starved fish were weighed individually, and groups of 40 fish (Av. body wt. $1.8 \mathrm{~g}$ ) were introduced into the respective $200 \ell$ polycarbonate circular tank. Sandfiltered sea water was supplied continuously at a flow rate of $3-4 \ell / \mathrm{min}$. The water temperature varied within $24.5-26.2^{\circ} \mathrm{C}$. Fish were fed to satiation twice a day for 10 weeks. Body weight was measured biweekly at about 15 hours after a last feeding. After weighing, fish were bathed in the respective tank with sodium nifurstyrenate (sodium salt of 5-nitro-2-(p-carboxy styryl)-furan) to prevent any bacterial attack or injury that might be caused due to handling (Sugimoto et al., 1976).

\section{Sample collection and analytical method}

At the end of rearing experiment, fish were anesthetized with over exposure to MS222 (3-aminobenzoic acid ethyl ester). Body weight and body length were recorded. Blood was collected with the insertion of $1 \mathrm{~m} \ell$ heparinized syringe from the heart. Liver was collected and weighed for hepatosomatic index calculation. Liver was then preserved at $-20^{\circ} \mathrm{C}$ for further analyses.

Hematocrit value and plasma protein content were measured with a Kubota Hematocrit Reader (Hesser, 1960) and a ATAGO Serum Protein Refractometer, respectively. Hemoglobin content was determined using the cyanmethemoglobin method (Wintrobe, 1956) by a Spectrophotometer (Hitachi, U-2000). Triglyceride, cholesterol and mineral contents of the plasma were measured with a Rapid Blood Analyzer (RaBASuper, Chugai Pharmaceutical Co.).

Proximate composition was analyzed as follows: moisture was determined after drying in an oven at $105^{\circ} \mathrm{C}$ until constant weight; ash content by incineration in a muffle furnace at $560^{\circ} \mathrm{C}$ for $12 \mathrm{~h}$. Protein and fat were determined by Kjeldahl method and ether extraction in a soxhlet apparatus, respectively.

Bone was collected after steaming the fish body for a few minutes on a boiling water bath. Vertebrae were separated, and adhesive tissues and fat bodies were removed and washed with distilled water. The bone sample was then dried in an oven, ground to fine grains, and digested with a nitric acid-perchloric acid mixture. Minerals except $\mathrm{P}$ in the diets and bone samples were determined with an Atomic Absorption Spectrometer (Perkin Elmer-3300). P was determined with the molybdenum blue method.

Student's T-test was applied to determine the significance in difference between treatment means.

\section{RESULTS}

The biweekly growth is shown in Fig. 1. Details of the growth performance are presented in Table 4. Growth of the mineral non-supplemented group started to decrease from the 2nd week and was maintained low $(p<0.05)$ compared to the supplemented group at the end of rearing experiment. However, no remarkable difference was found between feed efficiencies of the groups. A shortage of minerals was found to greatly 


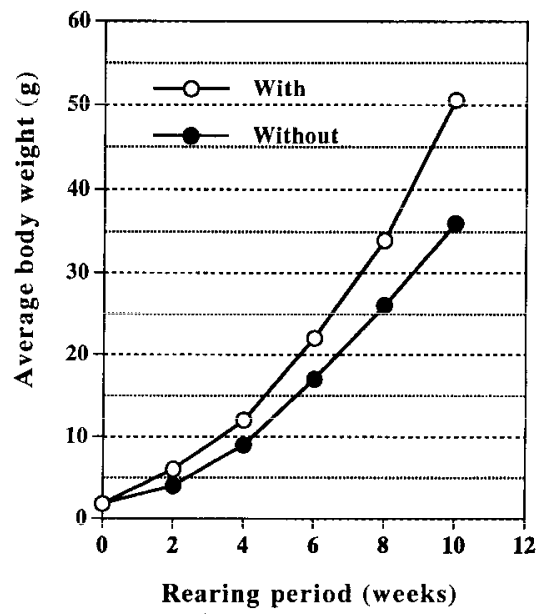

Fig. 1. Biweekly growth of tiger puffer fed on the experimental diets with or without a mineral mixture supplement.

Table 4. Growth and feed efficiency of tiger puffer fed on the experimental diets with or without a mineral mixture supplement

\begin{tabular}{ccc}
\hline & \multicolumn{2}{c}{ Mineral mixture supplement } \\
\cline { 2 - 3 } & With & Without \\
\hline Average body weight (g) & & \\
At start & $1.8 \pm 0.1$ & $1.8 \pm 0.1$ \\
After 10 weeks & $50.5 \pm 11.8$ & $30.6 \pm 6.4^{*}$ \\
Average weight gain (\%) & 2700 & 1900 \\
Feed efficiency (\%) & 91.3 & 89.8
\end{tabular}

Significant $(p<0.05)$.

affect the bone structure, as deformity of bone was found in $78.1 \%$ fish of the mineral non-supplemented group (Fig. 2).

Hemoglobin and hematocrit values were significantly high $(p<0.01)$ in the mineral non-supplemented group as shown in Table 5 . No remarkable difference between the groups was observed in plasma total protein, triglyceride, cholesterol, $\mathrm{Ca}, \mathrm{K}$ and $\mathrm{Fe}$ contents. $\mathrm{P}$ and $\mathrm{Mg}$ contents of plasma were markedly low in the mineral nonsupplemented group compared to the supplemented group (Table 5). No remarkable difference was found in the proximate composition of liver between the groups. Hepatosomatic index was lower in the non-supplemented group than the supplemented group (Table 6).

Lipid of the bone was higher in the non-supplemented group, but ash, P and Ca 

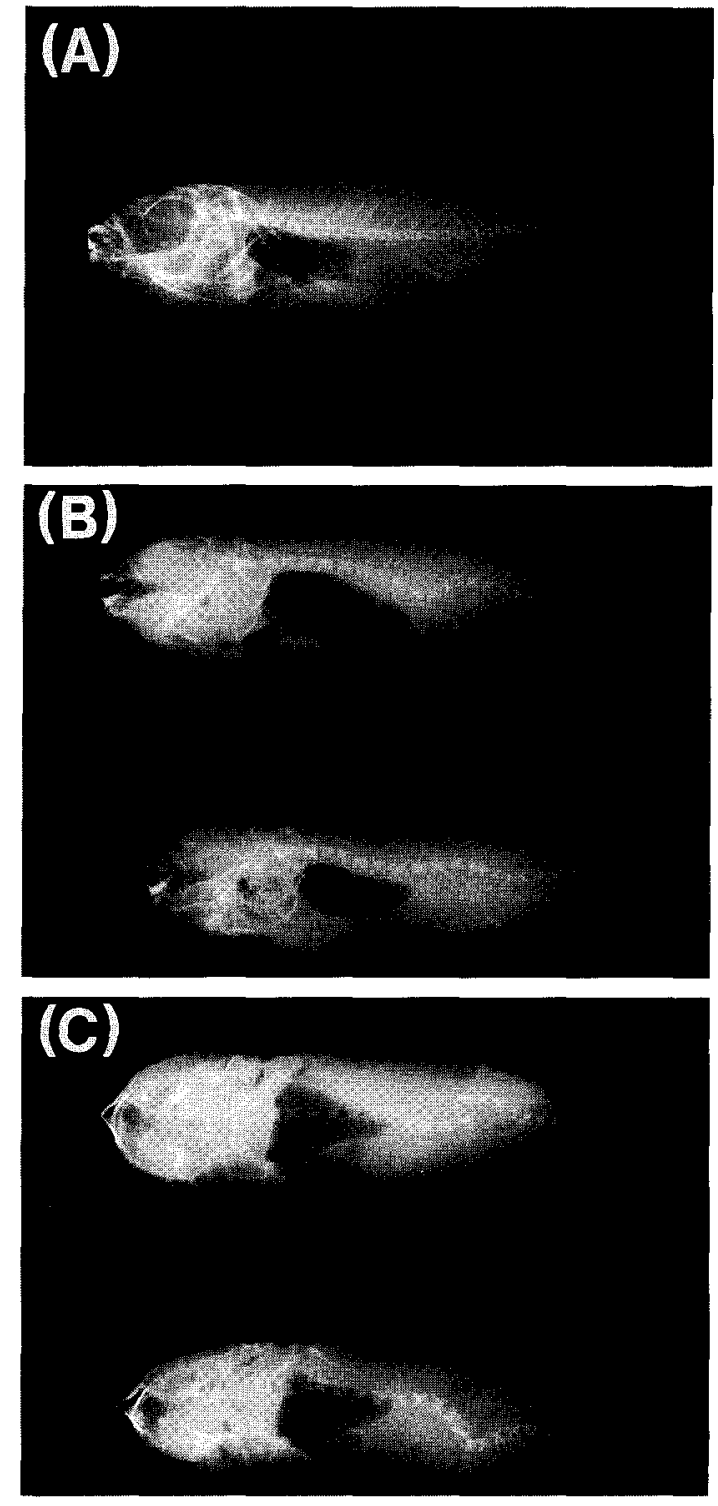

Fig. 2. Radiographs of tiger puffer fed on the experimental diets with (A: Lateral view) or without (B: Lateral view, C: Dorsal view) a mineral mixture supplement. 
Table 5. Blood characteristics of tiger puffer fed on the experimental diets with or without a mineral mixture supplement

\begin{tabular}{|c|c|c|}
\hline & \multicolumn{2}{|c|}{ Mineral mixture supplement } \\
\hline & With & Without \\
\hline Hemoglobin $(\mathrm{g} / 100 \mathrm{ml})$ & $4.8 \pm 0.8$ & $6.8 \pm 0.7^{*}$ \\
\hline Hematocrit $\quad(\%)$ & $22.1 \pm 2.4$ & $30.9 \pm 4.5^{*}$ \\
\hline \multicolumn{3}{|l|}{ (Plasma) } \\
\hline Total protein & $3.8 \pm 0.5$ & $3.9 \pm 0.5$ \\
\hline Triglyceride & 128 & 161 \\
\hline Total cholesterol $(\mathrm{mg} / 100 \mathrm{ml})$ & 236 & 207 \\
\hline $\mathrm{P} \quad(\mathrm{mg} / 100 \mathrm{ml})$ & 9.40 & 5.14 \\
\hline $\mathrm{Ca} \quad(\mathrm{mg} / 100 \mathrm{ml})$ & 16.0 & 14.0 \\
\hline $\mathrm{Ca} / \mathrm{P}$ ratio & 1.70 & 2.75 \\
\hline $\mathrm{Mg} \quad(\mathrm{mg} / 100 \mathrm{ml})$ & 4.53 & 1.62 \\
\hline $\mathrm{K} \quad(\mathrm{mg} / 100 \mathrm{ml})$ & 0.32 & 0.42 \\
\hline $\mathrm{Fe} \quad(\mu \mathrm{g} / 100 \mathrm{ml})$ & 55.1 & 57.5 \\
\hline
\end{tabular}

" Significant $(p<0.01)$.

Table 6. Proximate composition of liver and hepatosomatic index of tiger puffer fed on the experimental diets with or without a mineral mixture supplement

\begin{tabular}{lccc}
\hline & \multicolumn{2}{c}{ Mineral mixture supplement } \\
\cline { 2 - 3 } & & With & Without \\
\hline Moisture $\quad$ (\%) & 30.1 & 31.1 \\
Crude protein (\% d.m.) & 8.7 & 8.6 \\
Crude lipid & (\% d.m) & 89.1 & 90.9 \\
Crude ash & (\% d.m.) & 0.9 & 0.9 \\
Glycogen & (\% d.m.) & 1.7 & 2.0 \\
Hepatosomatic index ${ }^{* 1}$ & $8.64 \pm 1.31$ & $7.07 \pm 1.05^{* 3}$
\end{tabular}

${ }^{*}$ Liver wt (g) $\times 100 /$ body wt (g)

Significant $(p<0.01)$.

contents of bone were remarkably lower in the non-supplemented group than the supplemented one (Fig. 3).

\section{DISCUSSION}

In the present study, the poor growth and bone deformities were found in the mineral non-supplemented group (Fig. 2). Minerals in fish meal interact each other and exist as 

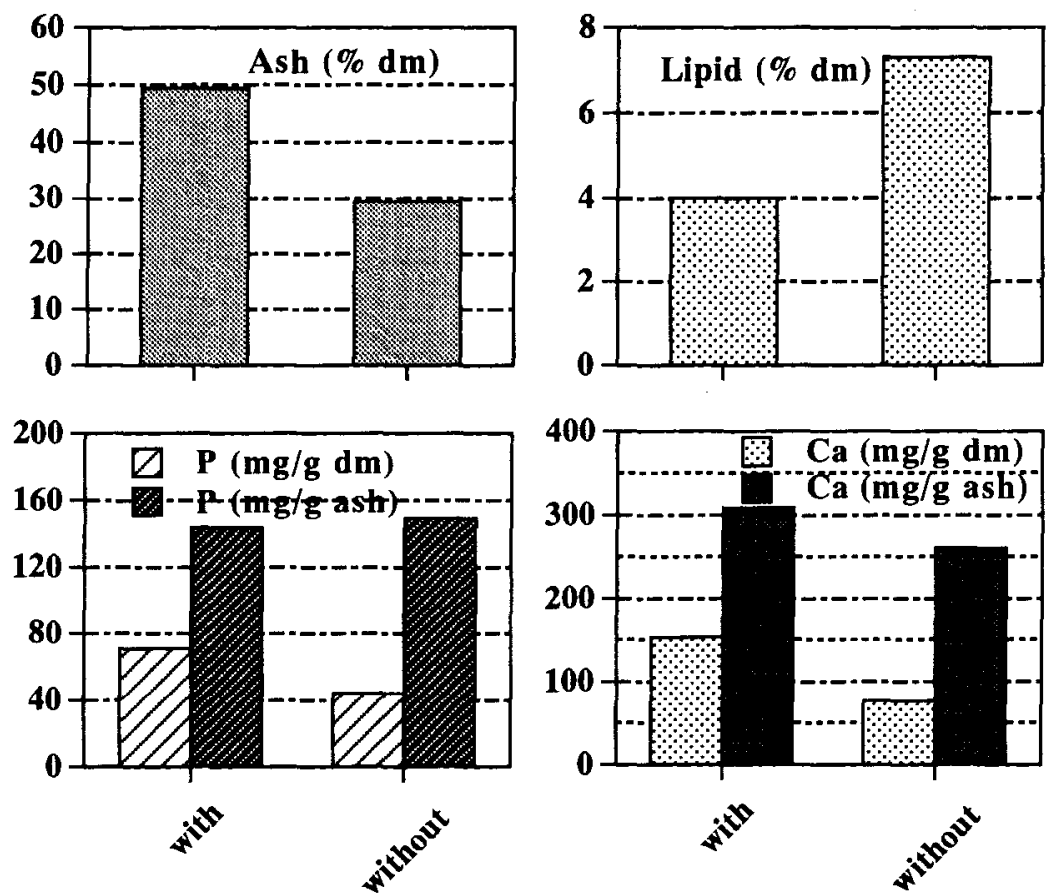

Fig. 3. Ash, lipid, phosphorus, and calcium contents of vertebrae of tiger puffer fed on the experimental diets with or without a mineral mixture supplement (dm: dry matter).

complex forms, resulting in less availability for tiger puffer. $\mathrm{P}$ and Ca exist as calcium phosphates, or more specifically hydroxyapatite, with very complicated structure. Tiger puffer, a stomachless fish, can not probably dissolve these complexes. The supplement of minerals to a white fish meal diet have been found to be effective for eel growth (Arai et al., 1974). Satoh et al." reported that $\mathrm{Zn}, \mathrm{Mn}, \mathrm{Mg}$, and $\mathrm{P}$ supplements are essential in the white fish meal diet for some marine fishes.

Hemoglobin and hematocrit values were significantly high in the non-supplemented group. However, deletion of minerals from a casein based diet lowered the hemoglobin and hematocrit values in red sea bream (Sakamoto, 1981). The differences may be due to the specific characteristics of the fish species. Higher bone lipid content in contrast to lower $\mathrm{P}$ contents of plasma and bone in the non-supplemented group suggests that $\mathrm{P}$ negatively affects the metabolism of lipid (Sakamoto, 1981). Lower bone ash content indicates less availability of minerals from a fish meal diet for bone mineralization. Lower levels of $\mathrm{P}$ in plasma and bone revealed that tiger puffer do not fully utilize the $\mathrm{P}$ in fish meal which exists mainly as a complex tricalcium phosphate or hydroxyapatite. So, a supplement of $\mathrm{P}$ to the fish meal diet for tiger puffer may be recommendable. $\mathrm{P}$ from a

*:Satoh, S. et al. : Abst. Metg. Japan. Soc. Fisheries Sci., April, 1993, p. 43 (in Japanese). 
form of hydroxyapatite was less available in common carp (stomachless fish) than rainbow trout (Ogino et al., 1979). Ca which also exists as a hydroxyapatite in fish meal was low in bone. But, unlike $\mathrm{P}$, fish depend on not only dietary source for $\mathrm{Ca}$ but also surrounding water $\mathrm{Ca}$. Investigations with purified diet showed that a dietary $\mathrm{Ca}$ supplement is dispensable for rainbow trout (Ogino and Takeda, 1978), carp (Ogino and Takeda, 1976) and red sea bream (Sakamoto and Yone, 1976b). Because, fish can actively absorb and utilize Ca from surrounding water (Lovelace and Podoliak,1952; Ichikawa and Oguri, 1961; Templeton and Brown, 1963; Lall, 1979; Love, 1980). However, in the present case, the lower bone $\mathrm{Ca}$ content indicates that Ca from fish meal is less available to tiger puffer. Furthermore, the present result suggests that tiger puffer can not sufficiently absorb Ca from sea water. A dietary Ca supplement was found to be essential to a purified diet for yellowtail. ${ }^{* 1}$ Dietary Ca also promoted the growth of Japanese eel, ${ }^{* 3}$ and channel catfish (Lovell and Li, 1978). So, more specific studies with the essentiallity of Ca supplement to the fish meal diet for tiger puffer are necessary. $\mathrm{Mg}$ was distinctly lower in plasma of non-supplemented group, which suggests the essentiallity of $\mathrm{Mg}$ supplement to the fish meal diet for tiger puffer. However, $\mathrm{Mg}$ supplement was not essential in a purified diet for red sea bream (Sakamoto and Yone, 1979). Further studies are necessary to clarify whether the low plasma $\mathrm{Mg}$ in the nonsupplemented group is due to the unavailability of $\mathrm{Mg}$ from diet or due to the effect of the unavailability of other minerals in diets.

In the present study, a lacking of mineral mixture supplement to a fish meal diet greatly affected the normal growth of tiger puffer. Plasma and bone contents of some minerals were also poor in the mineral non-supplemented group. The low availability of minerals from fish meal in tiger puffer was probably due to the absence of a true stomach, hence less digestibility of minerals.

\section{REFERENCES}

Arai, S., T. Nose and H. Kawatsu 1974 Effect of minerals supplemented to the fish meal diet on growth of eel, Anguilla japonica. Bull. Freshwater Fish. Res. Lab., 24: 95-100

Gatlin, III, D. M. and R. P. Wilson 1983 Dietary zinc requirement of fingerling channel catfish. J. Nutr., 113: $630-635$

Gatlin, III, D. M. and R. P. Wilson 1984 Zinc supplementation of practical channel catfish diets. Aquaculture, 41: $31-36$

Hesser, E. E. 1960 Methods for routine fish hematology. Prog. Fish-Cult., 22: 164-171

Ichikawa, R. and M. Oguri 1961 Metabolism of radionucleotides in fish. I. Strontium-calcium discrimination in gill absorption. Nippon Suisan Gakkaishi, 27: 351-357

Ketola, H. G. 1975 Requirement of Atlantic salmon for dietary phosphorus. Trans. Am. Fish. Soc., 104: $548-551$

Lall, S. P. 1979 Minerals in finfish nutrition, In "Finfish Nutrition and Technology" (ed. by J. E. Halver and K. Tiews), Vol. 1, Heenemann Verlagsgesellschaft Mbh, Berlin, pp. 85-97

Love, R. M. 1980 The Chemical Biology of Fishes, Vol. 2, Academic Press, New York, pp. 943

Lovelace, F. E. and H. A. Podoliak 1952 Absorption of radioactive calcium by brook trout. Prog. FishCult., 14: 154-158

Lovell, R. T. and Y. P. Li 1978 Dietary phosphorus requirement of channel catfish (Ictalurus punctatus). Trans. Am. Fish. Soc., 107: 617-621

Ogino, C. and H. Takeda 1976 Mineral requirements in fish-III. Calcium and phosphorus requirements in

${ }^{*}$ Arai, S. et al:: Abst. Metg. Japan. Soc. Fisheries Sci., April, 1975, p. 48 (in Japanese). 
carp. Nippon Suisan Gakkaishi, 42: 793-799

Ogino C. and H. Takeda 1978 Requirements of rainbow trout for dietary calcium and phosphorus, Nippon Suisan Gakkaishi, 44: 1019-1022

Ogino, C., L. Takeuchi, H. Takeda and T. Watanabe 1979 Availability of dietary phosphorus in carp and rainbow trout. Nippon Suisan Gakkaishi, 45: 1527-1532

Sakamoto, S. and Y. Yone 1976a Requirement of red sea bream for dietary iron- I . Rep. Fish. Res. Lab., Kyushu Univ., 3: 53-58

Sakamoto, S. and Y. Yone $1976 \mathrm{~b}$ Requirement of red sea bream for dietary Ca. Rep. Fish. Res. Lab., Kyushu Univ, 3: 59-64

Sakamoto, S. and Y. Yone 1979 Requirement of red sea bream for magnesium. Nippon Suisan Gakkaishi, 45: $57-66$

Sakamoto, S. 1981 Requirement and deficiency symptoms of dietary minerals in red sea bream. Rep. Fish. Res. Lab., Kyushu Univ., 5: 1-99

Satoh, S., H. Yamamoto, T. Takeuchi and T. Watanabe 1983a Effects on growth and mineral composition of rainbow trout of deletion of trace elements or magnesium from fish meal diet. Nippon Suisan Gakkaishi, 49: 425-429

Satoh, S., H. Yamamoto, T. Takeuchi and T. Watanabe 1983b Effect on growth and mineral composition of carp of deletion of trace elements or magnesium from fish meal diet. Nippon Suisan Gakkaishi, $\mathbf{4 9}$ : 431-435

Satoh, S., T. Takeuchi, Y. Narabe and T. Watanabe 1983c Effects of deletion of several trace elements from fish meal diets on growth and mineral composition of rainbow trout fingerlings. Nippon Suisan Gakkaishi, 49: 1909-1916

Satoh, S., T. Takeuchi and T. Watanabe 1987 a Effect of deletion of several trace elements from a mineral mixture in fish meal diets on mineral composition of gonad in rainbow trout and carp, Nippon Suisan Gakkaishi, 53: 281-286

Satoh, S., T. Takeuchi and T. Watanabe $1987 \mathrm{~b}$ Availability to rainbow trout of zinc in white fish meal and of various zinc compounds. Nippon Suisan Gakkaishi, 53: 595-599

Satoh, S., T. Takeuchi and T. Watanabe 1987c Avallability to carp of manganese in white fish meal and of various manganese compounds. Nippon Suisan Gakkaishi, 53: 825-832

Satoh, S., K. Tabata, K. Izume, T. Takeuchi and T. Watanabe 1987d Effect of dietary tricalcium phosphate on availability of zinc to rainbow trout. Nippon Suisan Gakkaishi, 53: 1199-1205

Shitanda, K., R. Azuma and M. Ukita 1979 Effect of phosphorus supplement to commercial diet on growth, feed efficiency, chemical component of serum and body with carp. Suisanzoshoku, 27: 26-32

Sugimoto, N., S. Ishibashi and Y. Yone 1976 On the effectiveness and safety of sodium nifurstyrenate as a chemotherapeutic agent for pseudotuberculosis of yellowtail. Rep. Fish. Res. Lab., Kyushu Univ., $\mathbf{3}$ : $33-43$

Takamatsu, C., E. Endoh, T. Hasegawa and T. Suzuki 1975 Effect of phosphate supplemented diet on growth of carp. Suisanzoshoku, 23: 55-60

Takeuchi, T., T. Watanabe, C. Ogino, M. Saito, K. Nishimura and T. Nose 1981 Effect of low protein-high calory diets and deletion of trace elements from a fish meal diet on reproduction of rainbow trout. Nippon Suisan Gakkaishi, 47: 645-654

Templeton, W. L. and V. M. Brown 1963 Accumulation of calcium and strontium by brown trout from waters in the United Kingdom. Nature, 198: 198-200

Watanabe,T., S. Satoh and T. Takeuchi 1988 Availability of minerals in fish meal to fish. Asian Fisheries Science, 1: 175-195

Wintrobe, M. M. 1956 Clinical Hematology. Lea and Febiger, Philadelphia, pp. 1185 